\title{
Effect of Glucose Administration on Biomass, $\beta$-Carotene and Protein Content of Dunaliella sp. under Mixotrophic Cultivation
}

\author{
Muhammad Fakhri ${ }^{1,2 *}$, Prive Widya Antika ${ }^{1}$, Arning Wilujeng Ekawati ${ }^{1}$, Nasrullah Bai Arifin ${ }^{1,2}$, Ating Yuniarti ${ }^{1,2}$ and \\ Anik Martinah Hariati ${ }^{1,2}$ \\ ${ }^{1}$ Study Program of Aquaculture, Faculty of Fisheries and Marine Science, Brawijaya University, Malang 65145, Indonesia \\ ${ }^{2}$ Aquatic Biofloc Research Group, Faculty of Fisheries and Marine Science, Brawijaya University, Malang 65145, Indonesia \\ * For correspondence: mfakhri@ub.ac.id \\ Recieved 14 July 2020; Accepted 08 October 2020; Published 10 January 2021
}

\begin{abstract}
Dunaliella $\mathrm{sp.}$ is a prospective green microalga that can utilize both organic and inorganic carbon simultaneously. This study was aimed to determine the influence of various glucose concentrations on biomass concentration, $\beta$-carotene, and protein content of Dunaliella sp. under mixotrophic cultivation. Different glucose supplementation of $0.05 \mathrm{~g} / \mathrm{L}, 0.10 \mathrm{~g} / \mathrm{L}, 0.15 \mathrm{~g} / \mathrm{L}$, and $0.20 \mathrm{~g} / \mathrm{L}$ were applied mixotrophically. The culture condition of Dunaliella sp. was also performed under photoautotrophic cultivation. The results exhibited that glucose administration significantly influenced the growth, biomass concentration, $\beta$-carotene, and protein production of Dunaliella sp. $(P<0.05)$. Supplementation of glucose in the mixotrophic culture remarkably improved cell growth, biomass production, $\beta$-carotene, and protein content of Dunaliella sp. compared to photoautotrophic culture. Increasing glucose concentration from 0.05 to $0.15 \mathrm{~g} / \mathrm{L}$ increased biomass yield, $\beta$-carotene, and protein content of Dunaliella sp. The maximum specific growth rate and biomass concentration were produced at the glucose administration of $0.15 \mathrm{~g} / \mathrm{L}$ with a value of 1.058 per day and $0.896 \mathrm{~g} / \mathrm{L}$, respectively. Moreover, supplementation of $0.15 \mathrm{~g} / \mathrm{L}$ glucose resulted in the highest $\beta$-carotene and protein content. The results also noted that nitrate and phosphate consumption was highly related to biomass, $\beta$-carotene, and protein content of Dunaliella sp. In conclusion, the supplementation of glucose under mixotrophic conditions could improve the biomass, $\beta$-carotene, and protein content of Dunaliella sp. and could be practically used in mass-scale production. (C) 2021 Friends Science Publishers
\end{abstract}

Keywords: Green microalgae; Growth rate; Mixotrophic; Organic carbon; Photoautotrophic

\section{Introduction}

Microalgae have long been applied as a good feed source for animals (Pauw and Persoone 1988; Muller-Feuga et al. 2003), an alternative renewable energy source, mainly biodiesel (Hossain et al. 2008), and feedstock for industrial application (Singh and Gu 2010). Dunaliella sp. is a potential microalga for animal feed and industry because it contains high essential fatty acid, protein, and $\beta$-carotene content (Morowvat and Ghasemi 2016). Conventionally, microalgae are cultivated under a photoautotrophic culture where cells conduct the photosynthesis process to generate biomass (Perez-Garcia et al. 2011). However, this way of growth produces a small amount of biomass concentration and slow algal growth because a self-shading process that diminishes light penetration into culture media would finally raise the cost of biomass harvesting (Cheirsilp and Torpe 2012).

The heterotrophic or mixotrophic method is an alternative way to overcome the low yield in photoautotrophic cultivation (Perez-Garcia et al. 2011; Wang et al. 2012). In heterotrophic cultivation, microalgae can utilize organic substrate as the carbon source (Chen 1996; Devi et al 2012). However, heterotrophic culture causes photosynthetic activity suppression, therefore, a synergy of autotrophic and heterotrophic (mixotrophic) would be preferable (Marquez et al. 1993; Smith et al. 2015).

Mixotrophic culture is a feasible method to produce microalga biomass by assimilating both $\mathrm{CO}_{2}$ and organic carbon concurrently and the process of anabolic and catabolic occurs simultaneously (Kaplan et al. 1986; Chojnacka and Marquez-Rocha 2004). Mixotrophic growth reduces the requirement for light and increases the cost efficiency of microalgal biomass production (Lee 2004). Moreover, mixotrophic culture can provide high cell concentration and accumulate photosynthetic pigments (ElSheekh et al. 2012) as well as enhance the protein content of microalgae (Perez-Garcia and Bashan 2015). Dittamart et al. (2014) explained that Scenedesmus spp. biomass was 17 times higher in mixotrophic culture than in photoautotrophic culture. Besides, mixotrophic cultivation improves biomass productivity of Chlorella vulgaris (Abreu et al. 2012; Melo et al. 2018).

To cite this paper: Fakhri M, PW Antika, AW Ekawati, NB Arifin, A Yuniarti, AM Hariati (2021). Effect of glucose administration on biomass, $\beta$-carotene and protein content of Dunaliella sp. under mixotrophic cultivation. Intl J Agric Biol 25:404-408 
Glucose is the most favorable organic carbon source for optimizing microalgal production. It promotes significant respiration and growth rates when compared to other organic carbon substrates (Ogbonna and Tanaka 1996). Boyle and Morgan (2009) explained that glucose has more energy content approximately $2.8 \mathrm{~kJ} /$ mole than acetate that produces about $0.8 \mathrm{~kJ} / \mathrm{mole}$. Cheah et al. (2018) reported that glucose addition under mixotrophic cultivation improved the biomass production of Chlorella sorokiniana. The study about the influence of glucose on biomass and $\beta$ carotene content of Dunaliella salina has been reported by Morowvat and Ghasemi (2016). However, the response of microalgae on the environment and nutrients is speciesspecific. Therefore, there is a necessity to analyze the biomass, $\beta$-carotene, and protein content of Dunaliella sp. under mixotrophic culture with the addition of glucose and photoautotrophic culture. We also evaluate the influence of trophic cultures on nitrate and phosphate utilization and their relationship to growth, $\beta$-carotene, and protein content of Dunaliella sp.

\section{Materials and Methods}

\section{Algae cultures and medium}

Dunaliella sp. was obtained from the Institute of Brackishwater Aquaculture, Jepara, Indonesia. Walne medium which contains: $100.0 \mathrm{~g} \mathrm{NaNO}_{3} ; 20.0 \mathrm{~g} \mathrm{NaH}_{2} \mathrm{PO}_{4}$; $33.6 \mathrm{H}_{3} \mathrm{BO}_{3} ; 0.36 \mathrm{MnCl}_{2} ; 1.3 \mathrm{~g} \mathrm{FeCl}_{2}$; and $45.0 \mathrm{~g}$ EDTA per liter were used to culture the cells. $1 \mathrm{~mL}$ of medium was supplemented to $1,000 \mathrm{~mL}$ of sterilized seawater.

\section{Experimental culture conditions}

Initially, Dunaliella sp. was grown under a photoautotrophic condition in batch mode. A logarithmic phase of Dunaliella sp. was utilized as inoculum in both photoautotrophic and mixotrophic treatments. For photoautotrophic culture, aeration was applied to provide $\mathrm{CO}_{2}$ within the culture. In terms of mixotrophic culture, four different glucose concentrations $(0.05,0.10,0.15$ and $0.20 \mathrm{~g} / \mathrm{L})$ were added to the culture. For all treatments, algae cultures were aerated by the air pump with an airflow rate of $1 \mathrm{~L} / \mathrm{min}$ and were incubated at the temperature of $28^{\circ} \mathrm{C}$ under constant illumination with a light intensity of 3,000 lux. The inoculum was cultivated into $2.5 \mathrm{~L}$ bottles (working volume of $1.5 \mathrm{~L}$ ) at a salinity of $15 \mathrm{ppt}$ and a $\mathrm{pH}$ of 7.5 . Initial cell concentration was adjusted at 1 x $10^{5}$ cells $/ \mathrm{mL}$. All treatments were carried out in triplicate.

\section{Growth analysis}

Neubauer hemocytometer (BOECO, Hamburg, Germany) was applied to count cell concentration. A specific growth rate $(\mu)$ was calculated as stated by Fogg and Thake (1987):

$$
\mu(/ \text { day })=\frac{\ln (\mathrm{x} 2)-\ln (\mathrm{x} 1)}{\mathrm{t} 2-\mathrm{t} 1}
$$

\section{Biomass analysis}

Microalga biomass was determined by using the gravimetric method. A Whatman GF/C Filter Paper was used to filter a $25 \mathrm{~mL}$ algal sample. First, distilled water was applied to clean the algal pellet. Then, the sample was dried at $105^{\circ} \mathrm{C}$ for 2 hours and finally, weighed after cooling in desiccators (Janssen et al. 1999).

\section{$\beta$-Carotene analysis}

$\beta$-carotene was analyzed and calculated by a suitable method according to Morowvat and Ghasemi (2016).

$$
\beta \text {-carotene }(\mu \mathrm{g} / \mathrm{mL})=25.2 \times \mathrm{A}_{450}
$$

\section{Protein analysis}

Protein was performed according to Lowry's method (1951) and calibrated with standard bovine serum albumin (BSA).

\section{Nitrate and phosphate analysis}

Nitrate and phosphate concentrations in the culture were measured by using the spectrophotometric method at 410 and $690 \mathrm{~nm}$, respectively (Boyd 1979). Nitrate and phosphate were analyzed in day 0 and day 4 of culture.

\section{Statistical analysis}

One way analysis of variance using S.P.S.S. 20.0 was applied to analyze data among the treatments. A level of significance was tested at $95 \%$.

\section{Results}

To determine the influence of photoautotrophic and mixotrophic culture on biomass, $\beta$-carotene, and protein content by Dunaliella sp., various concentrations of glucose ranging from 0.05 to $0.20 \mathrm{~g} / \mathrm{L}$ were added to the basal Walne medium, whereas the photoautotrophic system was conducted with an air pump for the source of inorganic carbon. Both photoautotrophic and mixotrophic cultivations were grown under batch cultivation for 4 days (Fig. 1). The results for specific growth rate, maximum cell concentration, biomass yield, $\beta$-carotene, and protein content are exhibited in Table 1. The highest specific growth rate $(1.058 \pm 0.002$ per day $)$, the maximum cell concentration $\left(6.893 \times 10^{6}\right.$ cells $\left./ \mathrm{mL}\right)$, and biomass yield $(0.896 \pm 0.004 \mathrm{~g} / \mathrm{L})$ were observed when Dunaliella sp. was administered with a glucose concentration of $0.15 \mathrm{~g} / \mathrm{L}$. These results were significantly higher compared to 0.05 , 0.10 , and $0.2 \mathrm{~g} / \mathrm{L}$ glucose $(P<0.05)$ (Table 1$)$. Increasing glucose administration from 0.05 to $0.15 \mathrm{~g} / \mathrm{L}$ increased the growth rate and biomass production of Dunaliella sp. However, when glucose concentration increased to 0.20 $\mathrm{g} / \mathrm{L}$, the growth rate and biomass production dropped about 3.49 and $11.61 \%$, respectively. 
Table 1: Specific growth rate, maximum cell concentration, biomass concentration, $\beta$ carotene, and protein content of Dunaliella sp.

\begin{tabular}{|c|c|c|c|c|c|}
\hline $\begin{array}{l}\text { Treatment } \\
\text { Glucose concentration }(\mathrm{g} / \mathrm{L})\end{array}$ & $\begin{array}{l}\text { Specific growth rate (per } \\
\text { day) }\end{array}$ & $\begin{array}{l}\text { Maximum cell concentration } \\
\left(\mathrm{x} 10^{6} \text { cells } / \mathrm{mL}\right)\end{array}$ & $\begin{array}{l}\text { Biomass concentration } \\
(\mathrm{g} / \mathrm{L})\end{array}$ & $\begin{array}{l}\beta \text {-carotene } \\
(\mu \mathrm{g} / \mathrm{mL})\end{array}$ & Protein $(\%)$ \\
\hline 0.00 (Photoautotrophic cultivation) & $0.940 \pm 0.002^{\mathrm{a}}$ & $4.287 \pm 0.037^{\mathrm{a}}$ & $0.456 \pm 0.004^{\mathrm{a}}$ & $6.067 \pm 0.022^{\mathrm{a}}$ & $16.990 \pm 0.362^{\mathrm{a}}$ \\
\hline 0.05 & $0.980 \pm 0.004^{\mathrm{b}}$ & $5.041 \pm 0.072^{\mathrm{b}}$ & $0.529 \pm 0.002^{\mathrm{b}}$ & $9.765 \pm 0.019^{b}$ & $21.701 \pm 0.276^{\mathrm{b}}$ \\
\hline 0.15 & $1.058 \pm 0.002^{\mathrm{e}}$ & $6.893 \pm 0.051^{\mathrm{e}}$ & $0.896 \pm 0.004^{\mathrm{e}}$ & $17.485 \pm 0.100^{\mathrm{e}}$ & $31.762 \pm 0.060^{\mathrm{e}}$ \\
\hline 0.20 & $1.021 \pm 0.002^{\mathrm{d}}$ & $5.928 \pm 0.046^{\mathrm{d}}$ & $0.792 \pm 0.004^{\mathrm{d}}$ & $13.630 \pm 0.038^{\mathrm{d}}$ & $27.965 \pm 0.147^{\mathrm{d}}$ \\
\hline
\end{tabular}

Means followed by different superscripts are significantly differences $(P<0.05)$

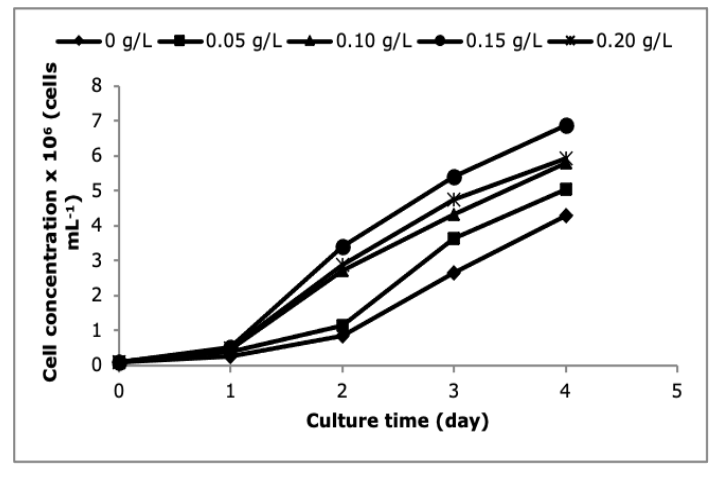

Fig. 1: Cell growth of Dunaliella spp. under mixotrophic and photoautotrophic cultivation

There was a significant difference in $\beta$-carotene and protein production under different glucose supplementation $(P<0.05)$. Overall, $\beta$-carotene content increased from 6.067 $\pm 0.022 \mu \mathrm{g} / \mathrm{mL}(0.05 \mathrm{~g} / \mathrm{L})$ to $17.485 \pm 0.100 \mu \mathrm{g} / \mathrm{mL}$ and protein content increased from $16.99 \pm 0.36$ to $31.762 \pm$ $0.06 \%$ when microalgae were treated from 0.05 to $0.15 \mathrm{~g} / \mathrm{L}$ (Table 1). However, when glucose supplementation increased to $0.20 \mathrm{~g} / \mathrm{L}$, the $\beta$-carotene dropped about $22 \%$ and protein content reduced approximately $11.95 \%$.

The supplementation of even the small concentration of glucose $(0.05 \mathrm{~g} / \mathrm{L})$ enhanced the maximum cell concentration and biomass yield by roughly 1.18 and 1.29 times, respectively, in comparison to the photoautotrophic cultivation. Moreover, the results produced in photoautotrophic cultivation showed a lower amount of $\beta$ carotene $(6.067 \pm 0.022 \mu \mathrm{g} / \mathrm{mL})$, and protein content (16.99 $\pm 0.362 \%$ ) than those observed in $0.05 \mathrm{~g} / \mathrm{L}$ glucose under mixotrophic cultivation (Table 1).

In this study, sodium nitrate was applied as a source of nitrogen for microalgae growth. The nitrate assimilation by Dunaliella sp. under various glucose supplementations and photoautotrophic cultivation was shown in Fig. 2. The provided bar graph shows that increasing glucose concentration from $0.05 \mathrm{~g} / \mathrm{L}$ to $0.15 \mathrm{~g} / \mathrm{L}$ led to an increase of nitrate utilization by Dunaliella sp. from 37.82 to $61.50 \%$. While the lowest nitrate utilization $(28.40 \%)$ was observed in photoautotrophic cultivation. This result indicates that mixotrophic cultivation is favorable for nitrate utilization by Dunaliella sp.

The phosphate utilization by Dunaliella sp. under mixotrophic and photoautotrophic cultivation was exhibited in Fig. 3. The results revealed that the

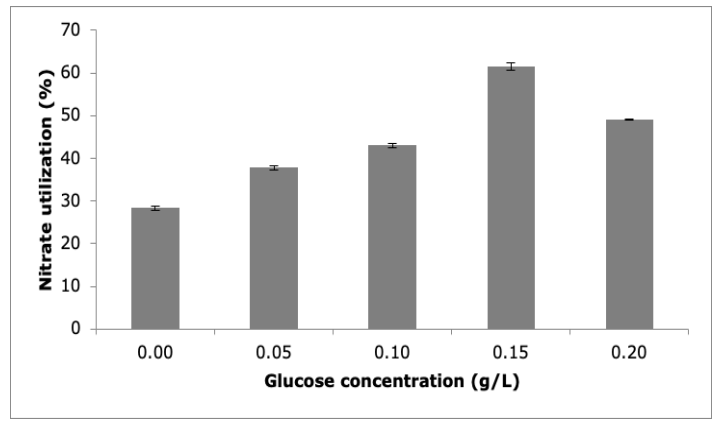

Fig. 2: Nitrate utilization by Dunaliella sp. under mixotrophic and photoautotrophic cultivation

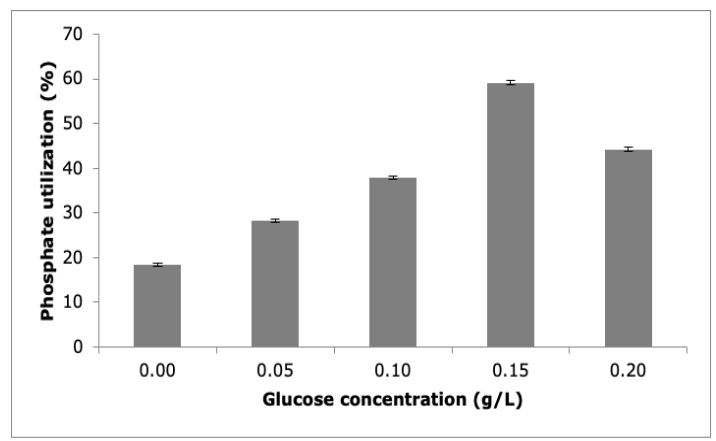

Fig. 3: Phosphate utilization by Dunaliella sp. under mixotrophic and photoautotrophic cultivation

utilization of phosphate was higher in mixotrophic that in photoautotrophic cultivation. Increasing glucose concentration from $0.05 \mathrm{~g} / \mathrm{L}$ to $0.15 \mathrm{~g} / \mathrm{L}$ led to an increase of phosphate utilization by Dunaliella sp. from 28.22 to $59.26 \%$.

\section{Discussion}

Photoautotrophic culture is a conventional method to grow microalgae by utilizing light as a source of energy and carbon dioxide as a source of inorganic carbon (Cheng et al. 2013). Nevertheless, some microalgae can improve their growth under a combination of photoautotrophic and heterotrophic conditions that allow the use of organic and inorganic carbon synergistically in the availability of light (Chojnacka and MarquezRocha 2004).

In this study, under mixotrophic cultivation, increasing 
glucose concentration from $0.05 \mathrm{~g} / \mathrm{L}$ to $0.15 \mathrm{~g} / \mathrm{L}$ improved growth rate, biomass concentration, $\beta$-carotene, and protein content significantly, however, the growth was inhibited when exposed to the highest glucose supplementation $(0.20$ g/L). Similarly, Wang et al. (2012) observed that cell growth and biomass concentration of Phaeodactylum tricornutum enhanced when glucose concentration was enhanced from 0.5 to $1.0 \mathrm{~g} / \mathrm{L}$ but restrained when the glucose concentration was raised to $2 \mathrm{~g} / \mathrm{L}$. Patel et al. (2009) reported the higher glucose supplementation from $2 \mathrm{~g} / \mathrm{L}$ to $10 \mathrm{~g} / \mathrm{L}$ resulted in higher biomass production from $3.38 \pm$ $0.16 \mathrm{~g} / \mathrm{L}$ to $4.32 \pm 0.32 \mathrm{~g} / \mathrm{L}$ in $P$. tricornutum without showed a negative influence in higher glucose concentration. Morowvat and Ghasemi (2016) reported that $D$. salina can utilize higher glucose concentration up to 15 $\mathrm{g} / \mathrm{L}$. These results prove that the ability of microalgae to utilize organic substrate is strain dependent.

The present study also found that when microalgae were cultured mixotrophically, cell growth, biomass concentration, $\beta$-carotene, and protein content were higher than microalgae cultured in photoautotrophic cultivation. This phenomenon is conforming to Liu et al. (2009) who noted that the cultivation of $P$. tricornutum under the mixotrophic condition on $100 \mathrm{~m} M$ glucose addition resulted in higher biomass $(0.555 \pm 0.01 \mathrm{~g} / \mathrm{L})$ than in photoautotrophic cultivation $0.460 \pm 0.003 \mathrm{~g} / \mathrm{L}$. This result is also similar to the reports for $C$. vulgaris (Liang et al. 2009) and Chlorella spp. PCH10 (Wang et al. 2016), where mixotrophic cultivation had higher biomass concentration than autotrophic cultivation. Morowvat and Ghasemi (2016) demonstrated that $\beta$-carotene content under a mixotrophic system increased 1.95 times than in photoautotrophic. Besides, the protein production in $D$. salina improved when the cells grown in mixotrophic culture (Kadkhodaei et al. 2015). Smith et al. (2015) explained that increased cell growth and biomass production in mixotrophic culture because the metabolic component of respiration and photosynthesis could work simultaneously, allowing an endogenic carbondioxide and oxygen source, and finally diminishes growth limitation.

Comparing Table 1 with Fig. 2, it can be seen that nitrogen utilization was higher under mixotrophic culture than under photoautotrophic culture. Moreover, when the nitrate utilization of Dunaliella sp. is high, its corresponding biomass concentration, $\beta$-carotene, and protein content are high. Kim et al. (2013) noted that the nutrient utilization of $C$. sorokiniana in photoautotrophic culture is lower than in mixotrophic culture. Wang et al. (2016) explained that the higher nitrate was utilized by $C$. vulgaris $\mathrm{PCH} 10$, the higher biomass concentration was produced. Nitrate is a key nutrient to support growth and is mainly converted into microalga protein (Hein et al. 1995). Singh et al. (2019) explained that nitrate is an essential factor in improving the intracellular accumulation of carotenoids in green microalgae.

The effect of trophic conditions on phosphorus utilization is also reported in this study. The result showed that the higher Dunaliella sp. assimilate phosphate resulted in the higher growth, $\beta$-carotene, and protein content of algae cells. Moreover, Dunaliella sp. cultured mixotrophically with the addition of glucose utilized higher phosphate compared to Dunaliella sp. grown photoautotrophically. Wang et al. (2016) explained that phosphorus has a great effect on the growth of microalgae, and it plays an essential role in energy transfer, metabolic control, and activation of the protein. A deficiency of phosphorus can influence the reduction of growth, pigment, and protein content of microalgae.

\section{Conclusion}

Supplementation of glucose under mixotrophic culture significantly affects the growth, biomass, $\beta$-carotene, and protein content of Dunaliella sp. Mixotrophic cultivation of Dunaliella sp. led to higher biomass, $\beta$ carotene, and protein content than photoautotrophic cultivation. We proposed that cell growth, biomass concentration, and protein content were related to nitrate and phosphate utilization of microalgae.

\section{Acknowledgements}

We are so thankful to the Faculty of Fisheries and Marine Science, Brawijaya University for providing financial support.

\section{Author Contributions}

Muhammad Fakhri, Prive Widya Antika, and Nasrullah Bai Arifin planned and conducted the experiments, Muhammad Fakhri and Arning Wilujeng Ekawati analyzed the results, Muhammad Fakhri wrote the manuscript, Ating Yuniarti and Anik Martinah Hariati edited and reviewed the manuscript and Prive Widya Antika and Nasrullah Bai Arifin statistically evaluated the data.

\section{References}

Abreu AP, B Fernandes, AA Vicente, J Teixeira, G Dragon (2012). Mixotrophic cultivation of Chlorella vulgaris using industrial dairy waste as organic carbon source. Bioresour Technol 118:61-66

Boyd CE (1979). Water Quality in Warmwater Fish Pond, p:359. Agricultural Experiment Station, Auburn University, USA

Boyle NR, JA Morgan (2009). Flux balance analysis of primary metabolism in Chlamydomonas reinhardtii. BMC Syst Biol 3; Article 4

Cheah WY, PL Show, JC Juan, JS Chang, TC Ling (2018). Enhancing biomass and lipid productions of microalgae in palm oil mill effluent using carbon and nutrient supplementation. Ener Conver Manage 164:188-197

Chen F (1996). High cell density culture of microalgae in heterotrophic growth. Trends Biotechnol 14:412-426

Cheng H, G Tian, J Liu (2013). Enhancement of biomass productivity and nutrients removal from pretreated piggery wastewater by mixotrophic cultivation of Desmodesmus spp. CHX1. Desalin Water Treat 51:7004-7011 
Cheirsilp B, S Torpee (2012). Enhanced growth and lipid production of microalgae under mixotrophic culture condition: Effect of light intensity, glucose concentration and fed-batch cultivation. Bioresour Technol 110:510-516

Chojnacka K, FJ Marquez-Rocha (2004). Kinetic and stoichiometric relationships of the energy and carbon metabolism in the culture of microalgae. Biotechnology 3:21-34

Devi MP, GV Subhash, SV Mohan (2012). Heterotrophic cultivation of mixed microalgae for lipid accumulation and wastewater treatment during sequential growth and starvation phases: Effect of nutrient supplementation. Renew Ener 43:276-283

Dittamart D, C Pumas, J Pekkoh, Y Peerapornpisal (2014). Effects of organic carbon source and light dark period on growth and lipid accumulation of Scenedesmus spp. AARL G022. Maejo Intl J Sci Technol 8:198-206

El-Sheekh MM, MY Bedaiwy, ME Osman, MM Ismail (2012). Mixotrophic and heterotrophic growth of some microalgae using extract of fungal-treated wheat bran. Intl J Recycl Org Waste Agric 1; Article 12

Fogg GE, B Thake (1987). Algae Cultures and Phytoplankton Ecology, p: 269. The University of Wisconsins Press, Madison, Wisconsin, USA

Hein M, MF Pedersen, K Sand-Jensen (1995). Size dependent nitrogen uptake in micro- and macroalgae. Mar Ecol Progr Ser 118:247-253

Hossain SABM, A Salleh, AN Boyce, P Chowdhury, M Naqiuddin (2008). Biodiesel fuel production from algae as renewable energy. Amer $J$ Biochem Biotechnol 4:250-254

Janssen M, TC Kuijpers, B Veldhoen, MB Ternbach, J Tramper, LR Mur, RH Wijffels (1999). Specific growth rates of Chlamydomonas reinhardtii and Chlorella sorokiniana under medium duration light/dark cycles: 13-87s. Progr Ind Microbiol 70:323-333

Kadkhodaei S, S Abbasiliasi, TJ Shun, HRF Masoumi, MS Mohamed, A Movahedi, R Rahime, AB Arif (2015). Enhancement of protein production by microalgae Dunaliella salina under mixotrophic conditions using response surface methodology. RSC Adv 5:3814138151

Kaplan D, AE Richmond, Z Dubinsky, S Aaronson (1986). Algal nutrition. In: Handbook for Microalgal Mass Culture, pp:147-198. Richmond A (Ed.). CRC Press, Boca Raton, USA

Kim S, J Park, YB Cho, SJ Hwang (2013). Growth rate, organic carbon and nutrient removal rates of Chlorella sorokiniana in autotrophic, heterotrophic and mixotrophic conditions. Bioresour Technol 144:813

Lee YK (2004). Algal nutrition. Heterotrophic carbon nutrition. In: Handbook of Microalgal Culture. Biotechnology and Applied Phycology, pp:166-124. Richmond A. (Ed.). Blackwell Publishing, Oxford, UK

Liang Y, N Sarkany, Y Cui (2009). Biomass and lipid productivities of Chlorella vulgaris under autotrophic, heterotrophic and mixotrophic growth conditions. Biotechnol Lett 31:1043-1049

Liu X, S Duan, A Li, N Xu, Z Cai, Z Hu (2009). Effects of organic carbon sources on growth, photosynthesis, and respiration of Phaeodactylum tricornutum. J Appl Phycol 21:239-246
Lowry OH, NJ Roseborough, AL Farr, RJ Randall (1951). Protein measurement with the folin phenol reagen. J Biol Chem 193:265275

Marquez FJ, K Sasaki, T Kakizono, N Nishio, S Nagai (1993). Growth characteristics of Spirulina platensis in mixotrophic and heterotrophic conditions. J Ferment Bioeng 76:408-410

Melo RBD, AF de Andrade, RP Bezerra, DS Correia, VC de Souza, AC Brasileiro-Vidal, DAV Marques, ALF Porto (2018). Chlorella vulgaris mixotrophic growth enhanced biomass productivity and reduced toxicity from agro-industrial by-products. Chemosphere 204:344-350

Morowvat MH, Y Ghasemi (2016). Culture medium optimization for enhanced B-carotene and biomass production by Dunaliella salina in mixotrophic culture. Biocatal Agric Biotechnol 7:217-223

Muller-Feuga A, R Robert, C Cahu, J Robin, P Divanach (2003). Uses of microalgae in aquaculture. In: Live Feeds in Marine Aquaculture, pp:253-288. Støttrup JG, LA McEvoy (Eds.). Blackwell Science, Oxford, United Kingdom

Ogbonna JC, H Tanaka (1996). Night time biomass loss and changes in biochemical composition of cells during light/dark cyclic culture of Chlorella pyrenoidosa. J Ferment Bioeng 82:558-564

Patel A, L Matsakas, K Hruzová, U Rova, P Christakopoulos (2019). Biosynthesis of nutraceutical fatty acids by the oleaginous marine microalgae Phaeodactylum tricornutum utilizing hydrolysates from Organosolv-Pretreated Birch and Spruce biomass. Mar Drugs 17; Article 119

Pauw ND, G Persoone (1988). Microalgae for aquaculture. In: Microalgal Biotechnology, pp: 197-221. Borowitzka MA, LJ Borowitzka (Eds.) Cambridge University Press, Cambridge, UK

Perez-Garcia O, Y Bashan (2015). Microalgal heterotrophic and mixotrophic culturing for bio-refining: from metabolic routes to techno-economics. In: Algal Biorefineries, pp: 61-131. Prokop A, R Bajpai, M Zappi (Eds.). Springer, Cham, Switzerland

Perez-Garcia O, FME Escalante, LE De-Bashan, Y Bashan (2011). Heterotrophic cultures of microalgae: Metabolism and potential products. Water Res 45:11-36

Singh DP, JS Khattar, A Rajput, R Chaudhary, R Singh (2019). High production of carotenoids by the green microalga Asterarcys quadricellulare PUMCC 5.1.1 under optimized culture conditions. PLoS One 14:e221930

Singh J, S Gu (2010). Commercialization potential of microalgae for biofuels production. Renew Sustain Ener Rev 14:2596-2610

Smith RT, K Bangert, SJ Wilkinson, DJ Gilmour (2015). Synergistic carbon metabolism in a fast growing mixotrophic freshwater microalgal species Micractinium inermum. Biomass Bioener 82:73-86

Wang H, R Fu, G Pei (2012). A study on lipid production of the mixotrophic microalgae Phaeodactylum tricornutum on various carbon sources. Afr J Microbiol Res 6:1041-1047

Wang YZ, PC Hallenbeck, GB Leite, K Paranjape, DQ Huo (2016). Growth and lipid accumulation of indigenous algal strains under photoautotrophic and mixotrophic modes at low temperature. Algal Res 16:195-200 